\title{
Variability during Marine Isotope Stages 11, 13 and 15 as revealed at IODP Sites U1313 and U1305 (North Atlantic)
}

Antje Voelker1, 2, Cristina Ventura1,2, Catarina Cavaleiro ${ }^{1,2}$, Andreia Rebotim ${ }^{1,2}$, Claude

Hillaire-Marcel ${ }^{3}$, Anne de Vernal ${ }^{3}$, Pamela Martin ${ }^{4}$

1: CIMAR Associated Laboratory, Rua dos Bragas, 289; 4050-123 Porto, Portugal

2: Unidade Geologia Marinha, LNEG, Estrada da Portela, Zambujal, 2610-143 Amadora, Portugal

3: Université du Québec à Montréal, Centre GEOTOP, CP 8888, succ. Centre-Ville, Montréal, Québec, Canada, H3C 3P8

4: The Dept. of the Geophysical Sciences, The University of Chicago, 5734 S. Ellis Ave., Chicago, IL 60637, USA

Surface and deep water proxy records from IODP Sites U1313 $\left(41^{\circ} \mathrm{N}, 33^{\circ} \mathrm{W}\right)$ in the midlatitude North Atlantic and U1305 $\left(57.5^{\circ} \mathrm{N}, 48.5^{\circ} \mathrm{W}\right)$ off the southern Greenland tip are used to compare the climatic variations during interglacial and interstadial Marine Isotope Stages (MIS) 11c, 13c, 13c, 15e and 15a. In the mid-latitude North Atlantic, surface and deep water records indicate that interglacial conditions were in general more stable during MIS 11c and 13a than during MS 15. Atlantic meridional overturning circulation (AMOC) was strong with North Atlantic Deep Water bathing Site U1313 during all the interglacials. Deep water ventilation was, however, reduced during MIS 15 and the mean grain size data furthermore shows that bottom current strength was stronger than during the younger interglacials and highly variable. The fastest switch to interglacial AMOC occurred at the onset of MIS 11c. G. inflata Mg/ Ca based temperature estimates for the winter mixed layer indicate that MIS $15 \mathrm{a}$ and $\mathrm{c}\left(10-12^{\circ} \mathrm{C}\right)$ were on average warmer than MIS 13 and 11c (10$11^{\circ} \mathrm{C}$ ). Interglacial variability within the winter mixed layer was higher during MIS 11c than 13. MIS 11c stands out because cooling started already at $405 \mathrm{ka}$, i.e. $>5 \mathrm{ky}$ prior to the end of interglacial warmth and to AMOC weakening (declining benthic $\delta^{13} \mathrm{C}$ values).

Off Greenland surface water warming was much stronger during MIS 11c than during MIS 13 as indicated by the strong decrease in \% N. pachyderma (s) (11c: 30-40\%; 13: 65-75\%) with no major difference between MS 13c and 13a. MIS11c had two warm phases interrupted by a short cooling. Ice-rafted debris input was minimal during both warm periods conform with a reduced Greenland ice-sheet (deVernal \& Hillaire-Marcel, 2008). Overall, Site U1305 shows variability more typical for the North Atlantic than the Nordic Seas indicating a rapid re-organisation of warm water currents in the North Atlantic at the onsets of the interglacials.

Talk at XVIII INQUA-Congress: Quaternary sciences - the view from the mountains.

21-27 July 2011 in Bern, Switzerland 